\title{
Quantitative estimates of the movement and distribution of North Atlantic right whales along the northeast coast of North America
}

\author{
Sean W. Brillant ${ }^{1,2,3, *}$, Angelia S. M. Vanderlaan ${ }^{2,4}$, Robert W. Rangeley ${ }^{1}$, \\ Christopher T. Taggart ${ }^{2}$ \\ ${ }^{1}$ WWF-Canada, Atlantic Region, Halifax, NS B3J 1P3, Canada \\ ${ }^{2}$ Oceanography Department, Dalhousie University, Halifax, NS B3H 4R2, Canada \\ ${ }^{3}$ Canadian Wildlife Federation, Halifax, NS B3H 4R2, Canada \\ ${ }^{4}$ Large Pelagics Research Center, University of Massachusetts Amherst, Gloucester, MA 01931, USA
}

\begin{abstract}
General movement patterns for North Atlantic right whales are known, but quantitative season-specific estimates of individual movements and the resultant distributions do not exist. We use a Brownian Bridge movement model to estimate individual movement patterns and spatial probability distributions using time- and location-specific photo-identified right whales from 1978 through 2007 to produce monthly estimates of movement and distribution patterns for the population in the NW Atlantic, from Cape Cod northward. For comparative purposes we also estimate right whale transition probabilities among ocean regions to estimate rates of emigration and immigration, likely destinations, and monthly regionally specific population estimates. Areas were identified that right whales may frequent and that are potential locations of the regularly unaccounted proportion of the population. These areas, requiring additional survey effort, include the Gulf of St. Lawrence, Scotian Shelf, Columbia Ledges and western Jordan Basin. Our results show that along the northeast Atlantic coasts of Canada and the USA, right whales annually migrate in a general counter-clockwise pattern; north and east along the continental shelf in the spring and summer, and south and west along the coast during autumn and winter. The results also provide quantitative spatio-temporal estimates of right whales for all regions, including those that are rarely or never surveyed. The spatial probability distributions that we provide can be used in the future to quantitatively evaluate risks to right whales from human activities, particularly vessel traffic and commercial fishing, and thereby increase our ability to manage the risks and improve right whale conservation.
\end{abstract}

KEY WORDS: Right whale $\cdot$ Time-space probability $\cdot$ Movement $\cdot$ Random walk $\cdot$ Brownian bridge

\section{INTRODUCTION}

The movement patterns of a species influence its population structure and distribution, and each is informative when designing conservation initiatives (e.g. Read \& Westgate 1997, Dodd \& Cade 1998, Hays et al. 2004). Knowledge of such patterns is necessary to identify and evaluate threats and risk to endan-

*Corresponding author: seanb@cwf-fcf.org gered species where risk reduction is essential for conservation. Movement data have been used for estimating how various threats may impact marine species and populations (e.g. Block et al. 2001, Hays et al. 2004, James et al. 2005). The North Atlantic right whale Eubalaena glacialis (Rosenbaum et al. 2000), hereafter right whale, is a highly mobile and endangered species that inhabits the heavily populated and Attribution Lis restricted. Authors and original publication must be credited. Publisher: Inter-Research · www.int-res.com 
industrialised Atlantic coast of North America and is one of the most endangered large whales (Caswell et al. 1999, Kraus et al. 2005). The population estimate for the species in 2012 was $509( \pm 30 \%)$ individuals (Right Whale Consortium 2012). The movement patterns of right whales and their distribution have considerable implications for conservation (Schick et al. 2009) given that the whales are exposed to a variety of adverse human activities (e.g. shipping, fishing) that are coincident with their distribution. By far the majority of documented right whale mortalities are attributable to vessel strikes and entanglement in commercial fishing gear (Moore et al. 2004, Kraus et al. 2005, Brown at al. 2009, van der Hoop et al. 2014).

Managing human activities that threaten the whales requires knowledge of times and locations where the whales and threats co-occur. There has lacked, however, an ability to predict time-specific locations of right whales, particularly during their migrations (Schick et al. 2009, Vanderlaan et al. 2011). Survey effort for right whales covers a small fraction (Fig. S1 in the Supplement at www.int-res.com/articles/suppl/ n027p141_supp.pdf) of their known distribution, and the effort is generally focused where the whales are known to aggregate seasonally - the so-called 'critical' habitats (Hamilton et al. 2007). Consequently, knowledge of where whales aggregate is sufficient only for managing local threats, but given their large migratory ambit (Kraus \& Rolland 2007), it is necessary to evaluate the threats within the ambit and in concert with time-specific estimates of whale locations if conservation is to be effectively achieved (Saher \& Schmiegelow 2005).

A simple and frequently used method for reconstructing migratory paths of animals is to assume that they travel in straight lines at constant velocity between pairs of observed locations (Morales et al. 2004). One limitation of this method is that there are no quantitative estimates of locations between 2 known locations and the uncertainty of intermediate locations increases with the time spent moving from one to the other. This limitation can be partially overcome using a Brownian Bridge movement model (BBMM) that provides probabilistic estimates between known locations (Horne et al. 2007). The BBMM is a conditional random-walk (i.e. stochastic) model where the start and end (of the bridge) are relatively accurate (known) locations and the variance in intermediate location estimates is largest mid-point of the bridge. The use of simple conditional random-walk models to estimate locations of animals has precedence (Turchin 1998, Lauzon-Guay et al. 2006, Nams 2006, van der Hoop et al. 2012, Papastamatiou et al. 2013).
Right whale photo-identification, sightings and limited satellite tagging data, each demonstrate frequent and extensive seasonal movements in, out, within and around various habitats (Kraus et al. 1986, Knowlton et al. 1994, Mate et al. 1997, Firestone et al. 2008). Although spatial and temporal distributions of right whales within many of the known habitats are well documented, there is a paucity of information concerning transitions and migration paths between and among the habitats. Although photo-identification records of individual right whales have been used for various reasons (extinction probabilities, Caswell et al. 1999, Fujiwara \& Caswell 2001; fishinggear entanglements and vessel strikes, Kraus 1990, Knowlton \& Kraus 2001, Knowlton et al. 2008; age structure and maturity, Hamilton et al. 1998; health assessment, Pettis et al. 2004; and migration and calving rates, Kraus et al. 1986), they have not been used to examine migratory movements in a comprehensive manner, nor to examine the whales' transition patterns among various well-known critical habitats (but see Vanderlaan 2009). Our focus here is to use a BBMM and transition probability estimates to quantitatively estimate the migratory pathways of right whales within and among several regions along the Northeast Atlantic coasts of Canada and the USA, and to evaluate the propensity for right whales to move among the regions on a seasonal basis.

\section{MATERIALS AND METHODS}

\section{Movement model}

The study domain for the BBMM was between 40 and $51^{\circ} \mathrm{N}$ latitude and 48 and $71^{\circ} \mathrm{W}$ longitude, subdivided into $3^{\prime}\left(0.05^{\circ} \mathrm{N}\right.$ and $\left.\mathrm{W}\right)$ grid-cells (76 620 gridcells, excluding the region landward of the coastline). We refer to various different regions within this domain: the South (locations south of $40^{\circ} \mathrm{N}$ ); Cape Cod Bay; the Great South Channel; the Columbia and Jeffreys Ledges and Jordan Basin collectively referred to as the Gulf of Maine; the Bay of Fundy, Roseway Basin; and the Northeast (locations east of Roseway Basin and/or northeast of $45.5^{\circ} \mathrm{N}$, including the Gulf of St. Lawrence; Fig. 1).

We used the North Atlantic Right Whale Consortium (NARWC) Identification Database (Right Whale Consortium 2008), containing 34580 date and location records among 528 individually identified right whales over the period 1978 through 2007, to extract all data for those whales within the study domain that were identified and located more than once with no 


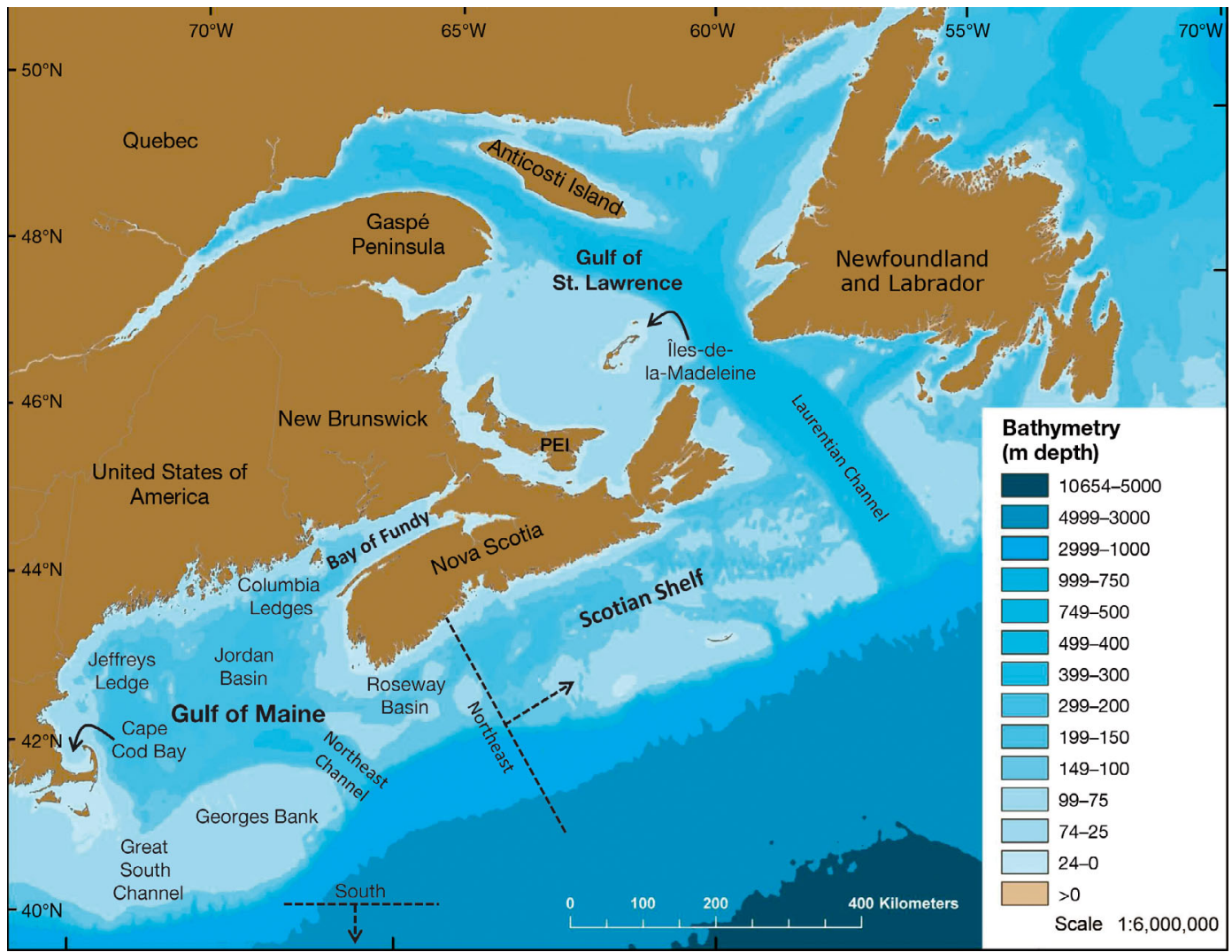

Fig. 1. Map of the study area depicting bathymetry and the areas mentioned throughout this research. This format is the same used for all maps presented in the main article and in the Supplement

more than $30 \mathrm{~d}$ of elapsed time between consecutive locations (Fig. S2 in the Supplement at www.int-res. com/articles/suppl/n027p141_supp.pdf). This timeframe was chosen to reduce the variability in estimating locations of whales between consecutive known locations, and it included 0.72 of all the available observations. We defined a whale 'track' as any set of at least 2 consecutive locations of the same individual spanning a period of no more than $30 \mathrm{~d}$ between any pair of consecutive locations, i.e. an individual whale could produce many tracks within each of which no consecutive locations spanned a period greater than $30 \mathrm{~d}$. For example, the whale-track of the longest duration was attributed to right whale EG2303 which was identified and located 16 times over a period of $159 \mathrm{~d}$ (April through August 2001). The whale-track consisting of the most observations was attributed to EG1610 which was identified and located 51 times over a $91 \mathrm{~d}$ period from July through October of 1986. Sets of consecutive locations allowed us to determine 3666 unique whale-tracks composed of 22454 knownwhale locations from which we used the BBMM to estimate an additional 6516 daily locations for a total of 28970 observed and estimated locations (Table 1).
Table 1. Monthly summary of North Atlantic right whale (Eubalaena glacialis) location data used in this research. Observed locations are the number of photo-identified right whale locations from the database (Right Whale Consortium 2008) used in the Brownian Bridge Model. Estimated locations are the number of whale locations estimated by the model between observed locations. The number of non-zero grid-cells is the number of $3^{\prime}\left(0.05^{\circ}\right)$ grid-cells within the domain containing non-zero probability estimates after the elimination of small probabilities $(<0.05362$; see 'Materials and methods - Limiting the probability results' for details)

\begin{tabular}{|lccc|}
\hline Month & $\begin{array}{c}\text { Observed } \\
\text { locations }\end{array}$ & $\begin{array}{c}\text { Estimated } \\
\text { locations }\end{array}$ & $\begin{array}{c}\text { No. of non-zero } \\
\text { grid-cells }\end{array}$ \\
\hline Jan & 207 & 85 & 88 \\
Feb & 530 & 199 & 326 \\
Mar & 1565 & 497 & 2296 \\
Apr & 1660 & 541 & 2477 \\
May & 1252 & 473 & 2249 \\
Jun & 1006 & 377 & 1189 \\
Jul & 1828 & 702 & 2520 \\
Aug & 8465 & 1772 & 5318 \\
Sep & 5006 & 1511 & 5142 \\
Oct & 784 & 322 & 954 \\
Nov & 97 & 22 & 66 \\
Dec & 54 & 15 & 15 \\
\hline
\end{tabular}


A notable feature of photo-identification data is that these data are not associated with measures of effort (e.g. searched area or duration) and cannot be corrected for biases in this way. The NARWC has protocols for establishing individually identified whales (Prescott 2013), and submitted photographs that meet these standards are included in the database as a record of a specific individual right whale. As a result, the database simply consists of individually identified right whales recorded at specific times and geographic coordinates. As this research is modelling behaviour to infer locations of the animals, this does not directly affect our analysis, but it is an inherent bias in detection that is common in many studies of movement patterns (e.g. Papastamatiou et al. 2013).

The basic BBMM we used for movement was defined by the mean and the variance of the expected location according to:

$$
\mu_{t}=a+\frac{\left(t-t_{1}\right)}{\left(t_{2}-t_{1}\right)}(b-a)
$$

where $\mu_{t}$ is the location of a whale at time $t \in\left(t_{1}, t_{2}\right), a$ is the location at $t_{1}, b$ is the location at $t_{2}$, and

$$
\sigma_{t}^{2}=\frac{\left(t-t_{1}\right)\left(t_{2}-t_{1}\right)}{\left(t_{2}-t_{1}\right)} \sigma_{\mathrm{m}}^{2}
$$

where $\sigma_{\mathrm{m}}^{2}$ is the coefficient of mobility (i.e. Brownian motion variance) related to the whale's rate of movement. This was calculated by numerically optimizing (maximizing) the likelihood function for $\sigma_{\mathrm{m}}^{2}$ (Horne et al. 2007).

The expected location of a whale moving from $a$ to $b$ at any time, $t\left[t \in\left(t_{1}, t_{2}\right)\right]$, was based on the normal distribution where the average location of the whale moves from $a$ to $b$ in a manner proportional to the time from $t_{1}$ to $t_{2}$ and with a variance $\sigma_{t}^{2}$. Thus, the bivariate probability density for all locations $z(z \in A)$ within the study area $(A)$ starting at location a was:

$$
\hat{p}_{t}^{a, b,\left(t_{1}, t_{2}\right)}(a, z)=\frac{1}{\sqrt{2 \pi \sigma^{2}}} \exp \left(\frac{-(z-\mu)^{2}}{2 \sigma^{2}}\right)
$$

Integrating Eq. (3) with respect to the 2 location variables $(x, y ; 2$-dimensional vectors) across the domain provided the probability that a given animal will be located at a given location within the domain over a given period $\left(t_{1}, t_{2}\right)$. Thus, the probability of locating an animal at location $z(z \in A)$ at time $t \in$ $\left(t_{1}, t_{2}\right)$ was estimated as:

$$
p\left(z_{t}\right)=\iiint \hat{p}_{t}^{a, b,\left(t_{1}, t_{2}\right)}(a, z) f_{a}(x) f_{b}(y) \mathrm{d} x \mathrm{~d} y \mathrm{~d} t
$$

where $f(x)$ and $f(y)$ are probability density functions of the 2 location variables $(x, y)$ in the domain.
For each given whale-track, the BBMM and its probability density function were used to calculate the probability that the given whale will be located in each of the 3' grid-cells in the domain for each day from the first to last observed location along the track. The daily grid-cell probabilities were summed over each calendar month across all whale-tracks and standardized to a sum of 1 . Thus, the location probabilities for right whales presented here are relative at a monthly resolution.

The nature of the BBMM, in our application, is such that the start and end locations (i.e. each known location of the identified whale) have zero variance. Thus, the probabilities of a whale being located at the start and end points of a track overwhelm the probabilities of it being at some intermediate location (i.e. $p=1, \sigma^{2}=0$ ). To eliminate this problem, we applied a small spatial variance $(0.004)$ to all known whale locations. This variance corresponds to the $5^{\text {th }}$ percentile of the variance among all known whale locations.

\section{Limiting the probability results}

A large number of the estimated probabilities of a whale being in a 3' grid-cell within a given month were extremely small (i.e. $\mathrm{p}<10^{-10}$ ). This is due to the fact that the model provides probability estimates across the entire study domain. We therefore limited the estimates to realistically useful predictions while ensuring the results were comparable among months. This was achieved by setting any estimated probability $<0.05362$ to zero. This threshold was selected to ensure that $7 \%$ (5318) of the grid-cells in the domain during the month with the most estimates (August) were non-zero values. This manner of eliminating the vanishingly small probabilities throughout most of the domain provided a standard threshold for the amount of data to be used, i.e. the largest probabilities within each month (Table 1).

\section{Transition probabilities and population estimates}

Dates and locations of photo-identified right whales from the NARWC Identification Database (detailed in the 'Movement model' sub-section above) were also used to estimate the transition probabilities of individual whales moving among a subset of the abovedefined regions that included the South, Cape Cod Bay, the Great South Channel, the Gulf of Maine, the Bay of Fundy, Roseway Basin and the Northeast, 
which includes all regions north and east of Roseway Basin, including the Gulf of St. Lawrence and Newfoundland (Fig. 1). Our only restriction on the data was to limit the analyses to 1980 through 2005, as data prior to 1980 were too few and those following 2005 were incomplete at the time the data were provided. Transition probabilities were estimated using the 'Movement' module of SOCPROG Ver. 2.4 (Whitehead 2009). This is a population-scale behaviour model that uses locations and times of photo-identified individuals to estimate movements and other variables of the population. Monthly identifications and locations were aggregated across years to provide insights into right whale occupancy in each defined region. A sampling interval of $30 \mathrm{~d}$ was used to estimate the transition probabilities as it allowed us to assume that a whale in any region could reach any other region within this interval, and it was consistent with the time limit used in the BBMM. We also used SOCPROG to estimate population size for regions among months across years. Bootstrap techniques (resampling with replacement) were used to estimate standard errors around each of the transition probability estimates and population size estimates.

\section{RESULTS}

\section{Movement model}

Individual right whale data

The data used for this research were very aggregated in space and time (Fig. S2 in the Supplement). More than 0.85 of the consecutive locations of individual whales occurred within $10 \mathrm{~km}$ of their subsequent location, and the duration between these known locations was between 0 and $16 \mathrm{~d}$. As a result of this and the scale at which we were modelling (3'-grid cells, approximately $5 \mathrm{~km}^{2}$ ), estimates for the coefficient of mobility for the BBMM, $\sigma_{\mathrm{m}}^{2}$ (i.e. Brownian motion variance), from an optimized likelihood function (Horne et al. 2007) were extremely small (average $=0.007$, maximum $=1.16$ ). Thus, we liberally set $\sigma_{\mathrm{m}}^{2}=1$.

\section{Regions with persistence and pattern}

The Brownian Bridge movement model identified 8 general regions where the probabilities of whale occurrence were persistent and relatively large for 2 or more months (Table 2, Fig. 2). Four were well-documented regions of seasonal aggregation that are frequently surveyed: Cape Cod Bay, the Great South Channel, the Bay of Fundy and Roseway Basin. The other regions of elevated and sometimes persistent probabilities were regions that are rarely or never surveyed (Fig. S1 in the Supplement), e.g. near the Jordan Basin and the Columbia and Jeffreys Ledges and elsewhere in the Gulf of Maine and the Gulf of St. Lawrence.

Changes in the monthly spatial probabilities of right whales being located in a given region indicated a clear seasonal pattern in their movements and evolving distribution (Table 2, Fig. 2). The BBMM estimated large ( $>0.3$, January through April) and persistent $(>0.003$, December through October) probabilities of whales being located in the Cape Cod Bay region (Table 2). Similarly large probabilities persisted over the May through June period in the Great South Channel and over the July through October period in the Bay of Fundy. Persistent probabilities occurred at much lower levels (0.05 to 0.07) from August through September in Roseway Basin and from July through August in the Gulf of St. Lawrence (0.002 to 0.005). Relatively unique and elevated probabilities occurred on Jeffreys Ledge (0.39) only in November and in Jordan Basin (0.96) only in December.

Table 2. Proportion of the monthly estimated distribution of North Atlantic right whales Eubalaena glacialis within each area of persistence. The probabilities for each month do not sum to 1 because whales may occur in areas outside of the areas of persistence that are listed here. Gaps represent 0

\begin{tabular}{|lcccccccccccc}
\hline Areas of persistence & Jan & Feb & Mar & Apr & May & Jun & Jul & Aug & Sep & Oct & Nov & Dec \\
\hline Cape Cod Bay & 0.876 & 0.768 & 0.410 & 0.342 & 0.058 & 0.003 & 0.008 & 0.004 & 0.004 & 0.042 & \\
Jordan Basin & 0.102 & & 0.005 & 0.007 & 0.002 & 0.003 & & 0.010 & 0.009 & & 0.041 \\
Jeffreys Ledge & & & 0.036 & 0.033 & 0.005 & 0.004 & 0.021 & 0.001 & & 0.004 & 0.394 \\
Great South Channel & & & 0.061 & 0.096 & 0.364 & 0.355 & 0.015 & & & & \\
Columbia Ledges & & & & & & 0.000 & 0.026 & 0.021 & 0.021 & 0.008 & \\
Bay of Fundy & & & & & 0.099 & 0.427 & 0.341 & 0.294 & 0.589 \\
Roseway Basin & & & & & & 0.010 & 0.051 & 0.073 & 0.023 & \\
Gulf of St. Lawrence & & & & & & 0.005 & 0.002 & & & \\
\hline
\end{tabular}



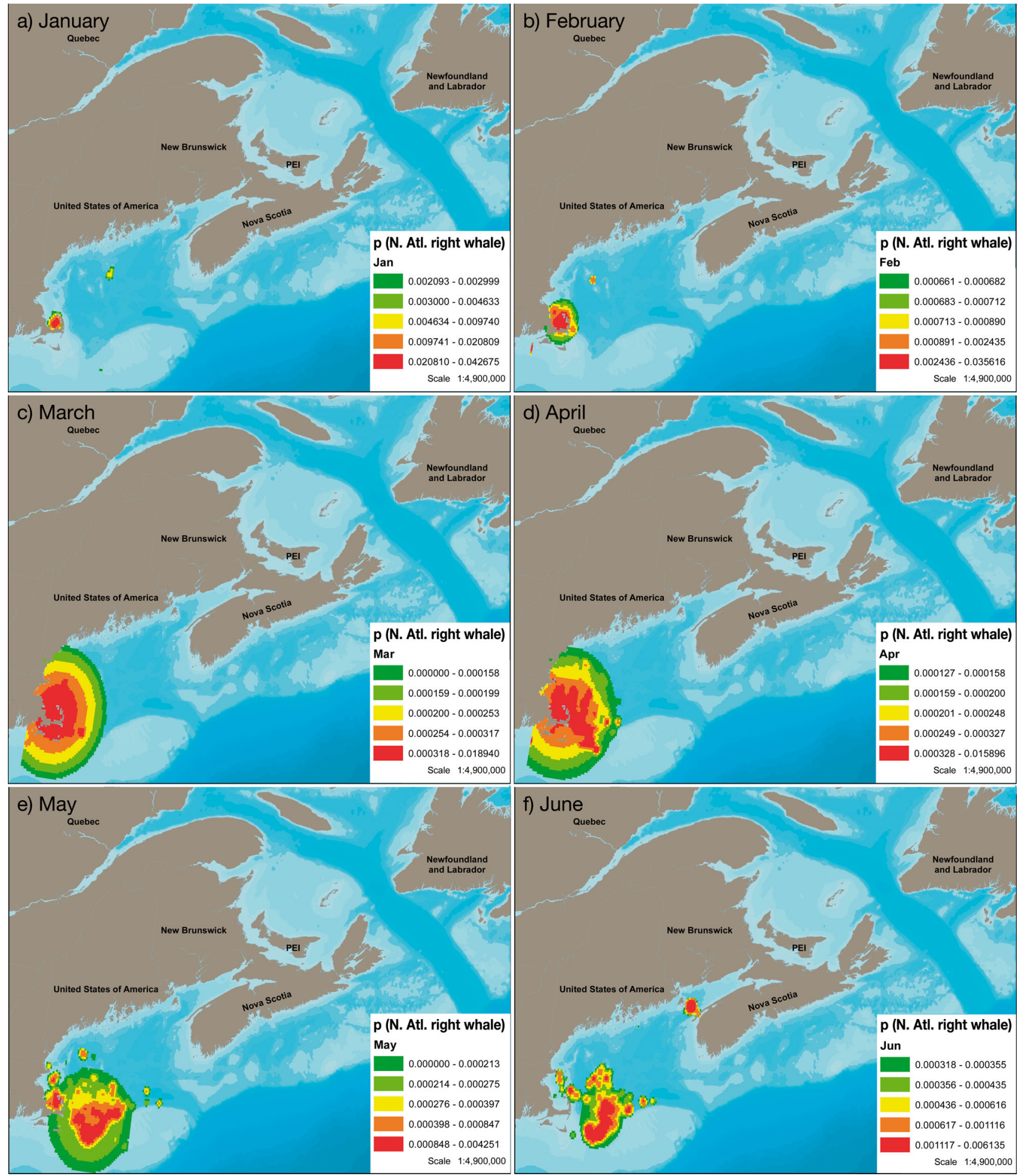

Fig. 2. Monthly probabilistic spatial distribution of North Atlantic right whales Eubalaena glacialis. These are relative annual probabilities (i.e. the sum of all probabilities over all months $=1$ ) of the occurrence of right whales. This standardization was done after raw probabilities $<0.05362$ were set to 0 . These relative annual probabilities are displayed in $0.05^{\circ}\left(3^{\prime}\right)$ grid-cells by colour representing the quantiles for each month; red cells are the largest probabilities (80 to $100 \%)_{\text {; }}$ orange $(60 \text { to } 80 \%)_{i}$ yellow (40 to $60 \%$ ); pale green (20 to $40 \%$ ); and green are the smallest (0 to $20 \%$ ). PEI: Prince Edward Island 


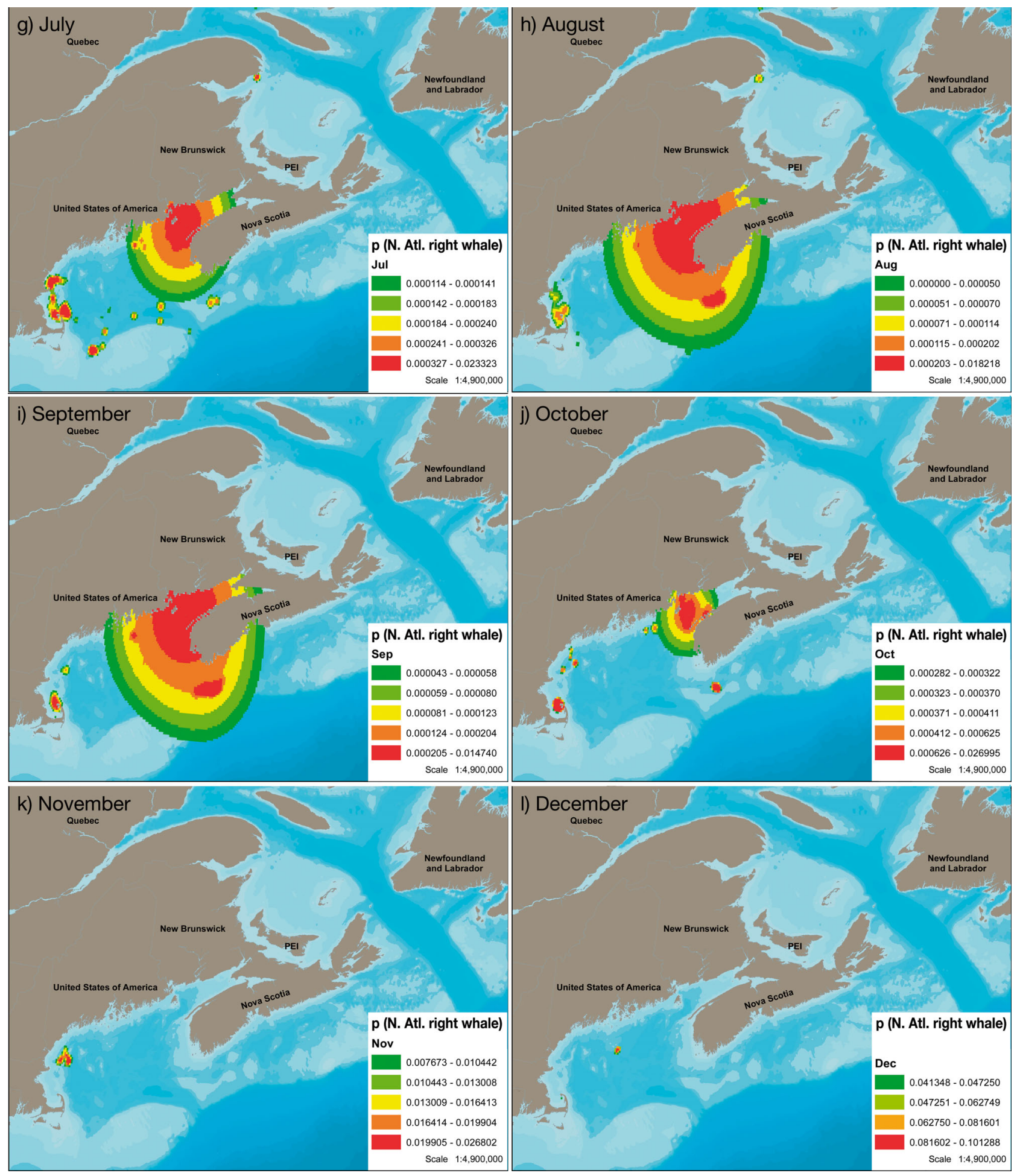

Fig. 2 (continued) 
The spatial probabilities indicated that right whales tend to move northeast from Cape Cod Bay during March through April and from the Great South Channel during June through July. The pattern of the largest changes in probabilities from Great South Channel between months suggests a migratory route along the northern edge of the Georges Bank (Fig. 2; see Fig. 1 for area names). It is not clear if or where the whales cross the Northeast Channel to move into the Bay of Fundy and Roseway Basin and the northeast, although, in July, the model does estimate that whales are located in the Northeast Channel.

In June, spatial probabilities began to increase in the Bay of Fundy and on the Jeffreys and Columbia Ledges and were largest in the Great South Channel. During July through October, the spatial probabilities indicated that right whales are most common in the Bay of Fundy but also occur consistently on Columbia and Jefferys Ledges and Roseway Basin. Probabilities are highest only on Jeffreys Ledge in November and in the Jordan Basin in December. One feature of these patterns was that northeastward emigration from Cape Cod Bay in spring indicated that the whales pass primarily through the Great South Channel and along the northern margin of Georges Bank, while southwestward emigration in autumn and winter indicated that they migrate primarily through the Jeffreys Ledge region (Fig. 2). Overall, this pattern suggests a general spring-through-autumn counter-clockwise immigration and emigration movement around the Gulf of Maine region, although there is much variation in these movements, as individual whales do move among different regions within seasons.

During summer there are relatively small but persistent probabilities of right whales occupying the Gulf of St. Lawrence, an area where there are few documented observations of right whales and virtually no surveys (Fig. S1 in the Supplement). Over the 30 yr period from 1978 through 2007, only 43 photoidentified right whales were recorded throughout the entire region, including the St. Lawrence River, the Îles-de-la-Madeleine and the northeast and southeast coasts of Newfoundland. Of these 43 observations, 11 whale-tracks met the requirements for BBMM, and the estimates indicated that 1 relatively small area within the Gulf of St. Lawrence was associated with large probabilities of whale occurrence: south of Cap d'Espoir on the Gaspé Peninsula (Fig. 2). The limited observations of right whales within the gulf precluded reasonable estimates of the migration routes through the region. Nonetheless, the Gulf of St. Lawrence appears to be an area where right whales likely persist from July through August.

\section{Transition probabilities and population estimates}

\author{
Patterns of emigration
}

The transition probabilities of individual whales moving among the 7 subset regions (South, Cape Cod Bay, the Great South Channel, the Gulf of Maine, the Bay of Fundy, Roseway Basin and to the Northeast) indicated that right whales in the Gulf of Maine and surrounding areas are very transitory, moving frequently among several areas throughout the year (Table S1 in the Supplement at www.intres.com/articles/suppl/n027p141_supp.pdf). Over all months, $58 \%$ (37 of 64 possible estimations) of the average probabilities that whales will emigrate from any of the 7 regions were $\geq 0.50$ (Fig. 3), although the bootstrap estimates of the standard errors around the estimates were very large (average standard error = 1.5 times the mean). Generally consistent with the BBMM results above, most of the elevated probabilities were associated with the May through October period. Whales were likely to emigrate from the South ( $p>0.50$ ) from May through October. Likewise, emigration from Cape Cod Bay occurs year-round, with elevated probabilities $(\mathrm{p}>0.50)$ in all months but January and February. Emigration from the Great South Channel and the Gulf of Maine also occurred in almost every month and was most likely $(p>0.80)$ during May and June for the former region and during April through August $(p>0.60)$ for the latter. Emigration from the Bay of Fundy was particularly elevated $(p>0.80)$ during July through October, while in Roseway Basin emigration was most elevated in October $(\mathrm{p}>0.70)$.

\section{Patterns of immigration}

Monthly destinations of right whales estimated from their transition probabilities (Table S1 in the Supplement) and their most likely destinations were rank ordered (Table 3). From December through April, Great South Channel and the Gulf of Maine were generally highly ranked, while the South and Cape Cod Bay regions typically ranked second or third. In May, destination rankings began to shift to Roseway Basin and Cape Cod Bay, the Gulf of Maine and the Great South Channel, and the Northeast. During June through October, rankings tended to vary in rank-order among all 7 regions, with the South and Roseway Basin most frequently ranked first. Notably, in September, neither the Bay of Fundy, nor Roseway Basin were highly ranked destinations. 

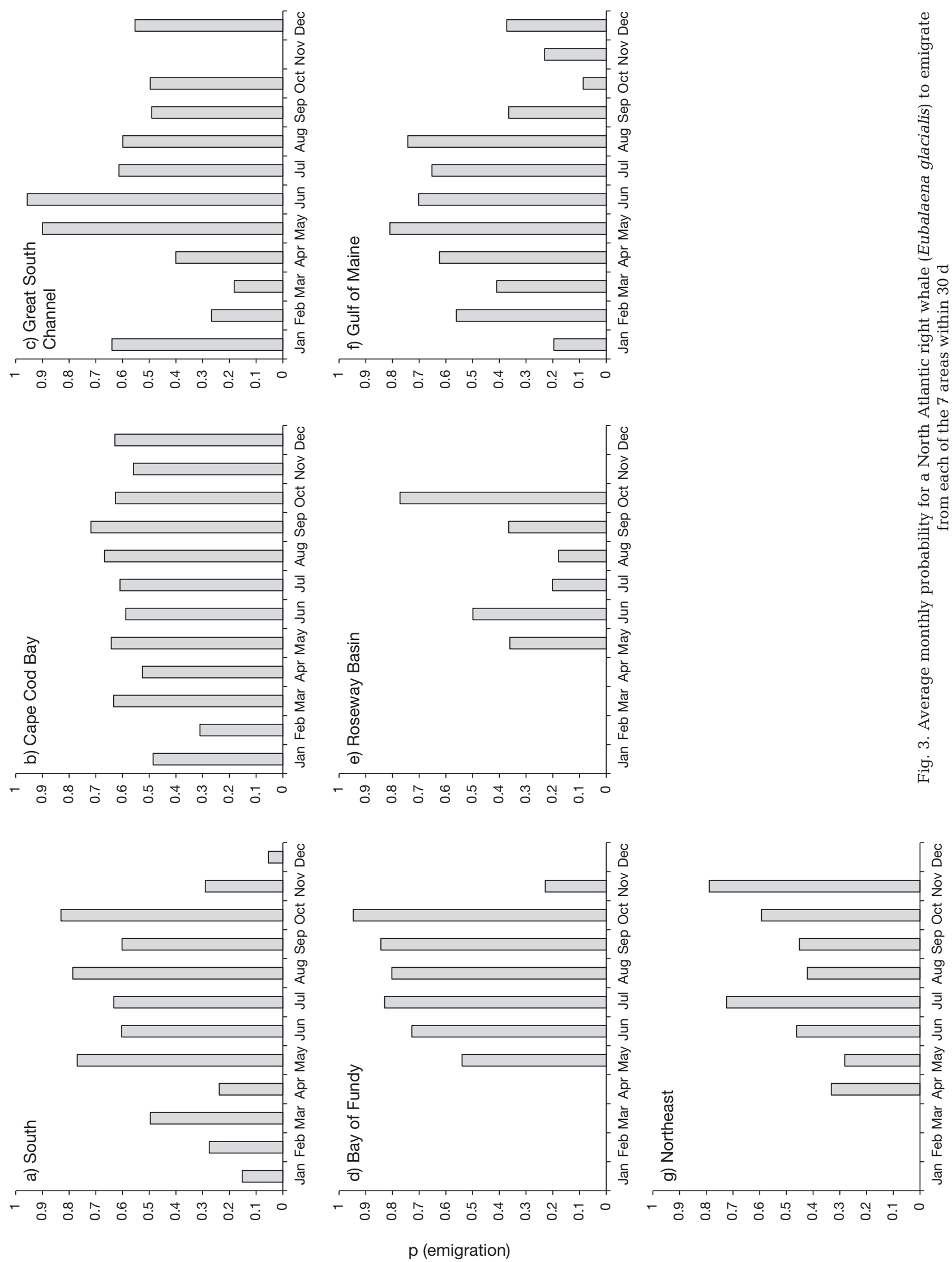
Table 3. Monthly rank-order of the regions that are the most likely destinations of emigrating North Atlantic right whales (Eubalaena glacialis) determined from the average transition probabilities of whales emigrating from all areas (see Table S1 in the Supplement at www.int-res.com/articles/suppl/n027p141_supp.pdf for details)

\begin{tabular}{|lccc|}
\hline Month & Rank 1 & Rank 2 & Rank 3 \\
\hline Jan & Gulf of Maine & South, Cape Cod Bay & Great South Channel \\
Feb & Great South Channel & South & Cape Cod Bay, Gulf of Maine \\
Mar & Great South Channel & Gulf of Maine & South, Cape Cod Bay \\
Apr & Great South Channel & South & Gulf of Maine \\
May & Roseway, Cape Cod Bay & Gulf of Maine & Northeast, Great South Channel \\
Jun & South & Gulf of Maine & Bay of Fundy, Northeast \\
Jul & Roseway Basin & Great South Channel, South & Bay of Fundy \\
Aug & Roseway Basin & Bay of Fundy & South, Northeast \\
Sep & South & Gulf of Maine \\
Oct & Bay of Fundy & Cape Cod Bay, Great South Channel, Roseway & South, Gulf of Maine \\
Nov & Northeast & Bay of Fundy & Gulf of Maine \\
Dec & Gulf of Maine & Great South Channel & Cape Cod Bay \\
\hline
\end{tabular}

November marks yet another shift to the Northeast, the Bay of Fundy and the Gulf of Maine, in rank order.

\section{Population estimates}

Monthly local population-size estimates (Table 4) showed that the average total population of right whales was 213 (2 SD = 128). This estimate represents approximately half the population estimate of $393( \pm 50 \%$; Right Whale Consortium 2007) near the end of the study period for our analyses. However, the data used in our analyses span a $25 \mathrm{yr}$ period (1980 through 2005), when the population size was estimated to be much lower (Caswell et al. 1999, Fujiwara \& Caswell 2001). Thus, the 2007 population estimate was within the upper bound of 2 standard deviations of the estimate provided by our analyses (469), which is also within the bounds of contemporary estimates (Right Whale Consortium 2012). The proportions of the estimated whale population in each of 7 areas indicated a seasonal pattern (Table 4).
Population estimates for the South, Cape Cod Bay, Great South Channel and the Gulf of Maine, tended to relatively decrease from January toward August, while estimates for the Bay of Fundy and Roseway Basin tended to relatively increase from May towards August. Estimates for the Gulf of Maine and Great South Channel were generally lowest from July through September, when Roseway Basin reached a maximum. Estimates for the Bay of Fundy and the Gulf of Maine reached their maxima in November and January, respectively.

\section{DISCUSSION}

The results of the 3 analyses used in this study were generally consistent and provided 2 new insights into the movements and distribution patterns of right whales. The whales were shown to migrate annually among coastal regions of the northwestern North Atlantic in a general counter-clockwise pattern, moving north and east along the continental shelf in the spring and summer and south and west

Table 4. Monthly estimates of the North Atlantic right whale (Eubalaena glacialis) population for each of the 7 regions used to examine transition probabilities. Gaps represent 0

\begin{tabular}{|c|c|c|c|c|c|c|c|c|c|c|c|c|}
\hline Transition areas & Jan & Feb & Mar & Apr & May & Jun & Jul & Aug & Sep & Oct & Nov & Dec \\
\hline South & 67 & 57 & 27 & 116 & 26 & 52 & 23 & 26 & 35 & 3 & 27 & 49 \\
\hline Cape Cod Bay & 23 & 45 & 28 & 27 & 43 & 30 & 8 & 6 & 7 & 7 & 6 & 12 \\
\hline Great South Channel & 32 & 70 & 108 & 83 & 23 & 10 & 31 & 31 & 34 & 9 & & 52 \\
\hline Gulf of Maine & 90 & 20 & 41 & 45 & 34 & 37 & 11 & 16 & 21 & 42 & 45 & 76 \\
\hline Bay of Fundy & & & & & 21 & 39 & 25 & 28 & 19 & 5 & 50 & \\
\hline Roseway Basin & & & & & 71 & 33 & 99 & 116 & 41 & 7 & & \\
\hline Northeast & & & & 55 & 83 & 51 & 19 & 38 & 34 & 2 & 17 & \\
\hline Total & 212 & 192 & 204 & 326 & 301 & 252 & 216 & 261 & 191 & 75 & 145 & 189 \\
\hline
\end{tabular}


along the coast during autumn and winter. Our results also demonstrate that individual right whales are highly mobile (transitory) during their migrations in their north-temperate habitats. From May through October in particular, right whales regularly departed from and returned to different regions, including regions that have not been surveyed.

A valuable contribution of this study lies in its ability to identify several areas that have not previously been identified as being associated with right whales. For example, the Columbia Ledges were associated with seasonally persistent probabilities for right whale occurrence, though the ledges have experienced little survey effort $(<200 \mathrm{~km}$ surveyed from 1978 to 2004) and few reported sightings of right whales $(<30)$. This area, and others, may be undetected locations of whale aggregations, or they may simply represent migratory routes frequently used by many individuals. Another finding from this study is that, during their migration from the Great South Channel to the Bay of Fundy in May and June, the whales do not appear to traverse directly across the Gulf of Maine but first move along the northern slope of Georges Bank. This interpretation is limited by a paucity of data (i.e. photo-identified whales) for intervening locations during these seasonal periods. Thus, the route right whales take from Georges Bank to Fundy or Roseway and the northeast is unknown, though the knowledge for managing adverse human activities is critical, e.g. vessels (Vanderlaan et al. 2009) and fishing gear (Vanderlaan et al. 2011) threats. We recommend that effort be invested to survey this area.

Another important result of this study is the ability to use the time-specific probabilistic estimates of right whale locations to quantitatively analyze the risks they face from human activities, such as vessel traffic or commercial fishing (Moore et al. 2004, Kraus et al. 2005, Brown at al. 2009). Prior to the present research, quantitative risk analyses of these activities were limited to areas of intensive surveys (Vanderlaan et al. 2008, 2011) or were based on general patterns of movement among regions. For example, the New England (USA) lobster fishery was identified as a threat to right whales for several reasons, including the timing of the fishery (Johnson et al. 2005, Myers et al. 2007). Conversely, the Canadian lobster fishery was found to be largely out of phase with right whales in Canadian waters (Vanderlaan et al. 2011). Other fisheries in Canada prosecuted during the summer, however, represent considerable threat that requires mitigation (Vanderlaan et al. 2011). The results of the present study will allow formal risk estimates to be quantified for the majority of regions addressed, including those areas that have yet to be surveyed adequately.

Part of the migratory pattern of right whales is thought to be linked to seasonal patterns of diapausing calanoid copepod concentrations at depth (Stone et al. 1988, Baumgartner \& Mate 2005, Michaud \& Taggart 2007, 2011, Pendleton et al. 2009, Davies et al. 2012), which represent their primary food source. Although it has not been determined if right whales are feeding in all regions, e.g. Gulf of St. Lawrence, this is a likely explanation that would account for their frequent transitions among regions during the summer and autumn, a behaviour observed in other species feeding on over-dispersed food resources (Johnson et al. 2002, Bowne \& Bowers 2004). The probabilistic occurrence of right whales in the Gulf of St. Lawrence and areas along the Scotian Shelf is noteworthy, because these may be locations of alternative and unknown feeding habitats (Mellinger et al. 2007). The paucity of photoidentified whales from the Scotian Shelf limits our ability to estimate how right whales move into the Gulf of St. Lawrence, though we can speculate that they migrate along the Scotian Shelf where there are several deep and copepod-rich basins (Sameoto \& Herman 1990). Alternative speculations include them moving along the shelf break or, less likely, east of the Scotian Shelf and entering the Gulf of St. Lawrence through the Laurentian Channel.

Our results also suggest that the Bay of Fundy (and potentially other areas occupied by right whales during summer and autumn) is an area to which whales frequently immigrate, emigrate from and then, at a later time, re-immigrate. Vanderlaan (2009) estimated this pattern of movement using lagged-identification rates, and it is consistent with observations from Mate et al. (1997) who tagged a small number of right whales in the Bay of Fundy and showed that many left the area only to return again later, some travelling a considerable distance in the intervening period. Such a pattern would explain inconsistencies among the conclusions drawn from the 3 analyses. Most notably, while the BBMM shows large probabilities for whale occurrence in the Bay of Fundy and Roseway Basin during September and emigration patterns show the Bay of Fundy as a highly ranked destination during the same period, the transition probabilities reveal that any given right whale has a high probability of leaving the Bay of Fundy during the same period.

Our results indicate that the seasonal distribution of right whales is most uncertain from November through February. Although the majority of pregnant females are known to arrive at the calving grounds 
along the southeast USA during this period (Kraus \& Rolland 2007, Firestone et al. 2008), the locations of the remainder of the population are largely unknown (Winn et al. 1986, Kenney et al. 2001; but see Cole et al. 2013). This may be a function of reduced survey effort in the northwestern Atlantic during the period or may simply be due to the fact that we do not know where to 'look' for right whales, even if they aggregate during this time. It is noteworthy that during this period the largest concentrations of copepods occur in the Gulf of Maine and Jordan Basin (Meise \& O'Reilly 1996).

We hope that the results of this research will help guide future survey efforts for right whales, because they identify regions and areas where the probabilities for right whale occurrence are elevated, while, at the same time, devoid of survey effort. Clearly, photoidentification data are notoriously biased, because areas with large annually persistent aggregations receive a disproportionate amount of attention (Hamilton et al. 2007). For example, of the 34580 records of photo-identified right whales in the database we used, 18105 were from the Bay of Fundy (Right Whale Consortium 2008). The opportunity to photo-identify right whales in areas where there has been little or no survey effort (e.g. Gulf of St. Lawrence, Scotian Shelf) is much more restricted, and this is reflected in the results of our research.

Knowing time-specific locations of North Atlantic right whales is necessary if efforts to protect them from deleterious human impact are to be achieved. Contemporary methods for tagging right whales are not feasible for population-scale monitoring of their distribution, and it is extremely costly to adequately survey the entire area over which right whales range. In this study, we used a simple, but relatively novel, approach by modelling the behaviour of individuals to provide a comprehensive probabilistic analysis of the space- and time-specific locations of the right whale population for the North Atlantic coast of Canada and the USA from Cape Cod and northward. Despite its limitations as a stochastic process, the basis for this research, the BBMM, was the simplest approximation to estimate unknown locations of right whales using the existing data, and the BBMM requires the fewest assumptions. The conclusions we have drawn benefit from being based on a relatively large number of individual whales (528) over a relatively long period $(\sim 30 \mathrm{yr})$. Thus, we have provided estimates that are practical and useful in quantitatively evaluating the risk to right whales from human activities external to areas where they are surveyed, i.e. improving our ability to manage the risks.
Acknowledgements. This work was supported by a WWFCanada post-doctoral fellowship award to S.W.B. through their partnerships with the CSL Group Inc., Fred and Elizabeth Fountain, and the Environment Canada Habitat Stewardship Program (HSP) for Species at Risk and through NSERC Discovery and HSP funds awarded to C.T.T. We thank the Northeast Atlantic Right Whale Consortium for data support, T. Wimmer for valuable advice and suggestions, G. Bondt for graphics support and H. Whitehead for support and assistance in the use of SOCPROG.

\section{LITERATURE CITED}

Baumgartner MF, Mate BR (2005) Summer and fall habitat of Northeast Atlantic right whales (Eubalaena glacialis) inferred from satellite telemetry. Can J Fish Aquat Sci 62: 527-543

Block BA, Dewar H, Blackwell SB, Williams TD and others (2001) Migratory movements, depth preferences, and thermal biology of Atlantic bluefin tuna. Science 293: 1310-1314

Bowne DR, Bowers MA (2004) Interpatch movements in spatially structured populations: a literature review. Landscape Ecol 19:1-20

Brown MW, Fenton D, Smedbol K, Merriman C, RobichaudLeblanc K, Conway JD (2009) Recovery strategy for the Northeast Atlantic right whale (Eubalaena glacialis) in Atlantic Canadian waters [Final]. Species at Risk Act Recovery Strategy Series. Fisheries and Oceans Canada, Ottawa

Caswell H, Fujiwara M, Brault S (1999) Declining survival probability threatens the Northeast Atlantic right whale. Proc Natl Acad Sci USA 96:3308-3313

Cole TVN, Hamilton P, Henry AG, Duley P, Pace RM III, White BN, Frasier T (2013) Evidence of a North Atlantic right whale Eubalaena glacialis mating ground. Endang Species Res 21:55-64

Davies KTA, Ryan A, Taggart CT (2012) Measured and inferred gross energy content in diapausing Calanus spp. in a Scotian Shelf basin. J Plankton Res 34:614-625

> Dodd CK Jr, Cade BS (1998) Movement patterns and the conservation of amphibians breeding in small, temporary wetlands. Conserv Biol 12:331-339

> Firestone J, Lyons SB, Wang C, Corbett JJ (2008) Statistical modeling of Northeast Atlantic right whale migration along the mid-Atlantic region of the eastern seaboard of the United States. Biol Conserv 141:221-232

Fujiwara M, Caswell H (2001) Demography of the endangered Northeast Atlantic right whale. Nature 414:537-541

> Hamilton PK, Knowlton AR, Marx MK, Kraus SD (1998) Age structure and longevity in North Atlantic right whales Eubalaena glacialis and their relation to reproduction. Mar Ecol Prog Ser 171:285-292

Hamilton PK, Knowlton AR, Marx MK (2007) Right whales tell their own stories: the photo-identification catalog. In: Kraus SD, Rolland RM (eds) The urban whale: Northeast Atlantic right whales at the crossroads. Harvard University Press, Cambridge, MA, p 75-104

> Hays GC, Houghton JDR, Myers AE (2004) Endangered species: pan-Atlantic leatherback turtle movements. Nature 429:522

$>$ Horne JS, Garton EO, Krone SM, Lewis JS (2007) Analyzing animal movements using Brownian bridges. Ecology 88: 2354-2363 
James MC, Myers RA, Ottensmeyer CA (2005) Behaviour of leatherback sea turtles, Dermochelys coriacea, during the migratory cycle. Proc R Soc B 272:1547-1555

Johnson CJ, Parker KL, Heard DC, Gillingham MP (2002) Movement parameters of ungulates and scale-specific responses to the environment. J Anim Ecol 71:225-235

Johnson A, Salvador G, Kenney J, Robbins J, Landry S, Clapham P (2005) Fishing gear involved in entanglements of right and humpback whales. Mar Mamm Sci 21: 635-645

Kenney RD, Mayo CA, Winn HE (2001) Migration and foraging strategies at varying spatial scales in western Northeast Atlantic right whales: a review of hypotheses. J Cetacean Res Manag Spec Issue 2:251-260

Knowlton AR, Kraus SD (2001) Mortality and serious injury of northeastern right whales (Eubalaena glacialis) in the western Northeast Atlantic Ocean. J Cetacean Res Manag Spec Issue 2:193-208

Knowlton AR, Kraus SD, Kenney RD (1994) Reproduction in Northeast Atlantic right whales (Eubalaena glacialis). Can J Zool 72:1297-1305

Knowlton AR, Cooper LA, Hamilton PK, Marx MK, Pettis HM, Kraus SD (2008) Analysis of scarring on Northeast Atlantic right whales (Eubalaena glacialis): monitoring rate of entanglement interaction-1980-2004. Final report to National Marine Fisheries Service, Contract No. EA133F-03-SE-0323, National Marine Fisheries Service, Boston, MA

Kraus SD (1990) Rates and potential causes of mortality in Northeast Atlantic right whales (Eubalaena glacialis). Mar Mamm Sci 6:278-291

Kraus SD, Rolland RM (2007) Right whales in the urban ocean. In: Kraus SD, Rolland RM (eds) The urban whale: Northeast Atlantic right whales at the crossroads. Harvard University Press, Cambridge, MA, p 1-38

Kraus S, Prescott J, Knowlton A, Stone G (1986) Migration and calving of right whales (Eubalaena glacialis) in the western Northeast Atlantic. Rep Int Whaling Comm Spec Issue 10:139-144

Kraus SD, Brown MW, Caswell H, Clark CW and others (2005) Ecology. Northeast Atlantic right whales in crisis. Science 309:561-562

Lauzon-Guay JS, Scheibling RE, Barbeau MA (2006) Movement patterns in the green sea urchin, Strongylocentrotus droebachaensis. J Mar Biol Assoc UK 86:167-174

Mate BR, Nieukirk SL, Kraus SD (1997) Satellite-monitored movements of the northeastern right whale. J Wildl Manag 61:1393-1405

Meise CJ, O'Reilly JE (1996) Spatial and seasonal patterns in abundance and age-composition of Calanus finmarchicus in the Gulf of Maine and on Georges Bank: 1977-1987. Deep-Sea Res I 43:1473-1501

> Mellinger DK, Nieukirk SL, Matsumoto H, Heimlich SL and others (2007) Seasonal occurrence of Northeast Atlantic right whale (Eubalaena glacialis) vocalizations at two sites on the Scotian Shelf. Mar Mamm Sci 23:856-867

Michaud J, Taggart CT (2007) Lipid and gross energy content of Northeast Atlantic right whale food, Calanus finmarchicus, in the Bay of Fundy. Endang Species Res 3: 77-94

> Michaud J, Taggart CT (2011) Spatial variation in right whale food, Calanus finmarchicus, in the Bay of Fundy. Endang Species Res 15:179-194

Moore MJ, Knowlton AR, Kraus SD, McLellan WA, Bonde RK (2004) Morphometry, gross morphology and available histopathology in Northeast Atlantic right whale (Eubalaena glacialis) mortalities (1970-2002). J Cetacean Res Manag 6:199-214

Morales JM, Haydon DT, Frair J, Holsiner KE, Fryxell JM (2004) Extracting more out of relocation data: building movement models as mixtures of random walks. Ecology 85:2436-2445

> Myers RA, Boudreau SA, Kenney RD, Moore MJ, Rosenberg AA, Sherrill-Mix SA, Worm B (2007) Saving endangered whales at no cost. Curr Biol 17:R10-R11

Nams VO (2006) Animal movement rates as behavioural bouts. J Anim Ecol 75:298-302

> Papastamatiou YP, Meyer CG, Carvalho F, Dale JJ, Hutchinson MR, Holland KN (2013) Telemetry and random-walk models reveal complex patterns of partial migration in a large marine predator. Ecology 94: 2595-2606

> Pendleton DE, Pershing AJ, Brown MW, Mayo CA, Kenney RD, Record NR, Cole TV (2009) Regional-scale mean copepod concentration indicates relative abundance of Northeast Atlantic right whales. Mar Ecol Prog Ser 378: 211-225

> Pettis HM, Rolland RM, Hamilton PK, Brault S, Knowlton AR, Kraus SD (2004) Visual health assessment of Northeast Atlantic right whales (Eubalaena glacialis) using photographs. Can J Zool 82:8-19

Prescott JH (2013) Data and photographic submission to the North Atlantic right whale identification database (catalog). New England Aquarium, Boston, MA. www. narwc.org

> Read AJ, Westgate AJ (1997) Monitoring the movements of harbour porpoises (Phocoena phocoena) with satellite telemetry. Mar Biol 130:315-322

Right Whale Consortium (2007) Northeast Atlantic Right Whale Consortium 2007 annual report card. Report to the Northeast Atlantic Right Whale Consortium November 2007. North Atlantic Right Whale Consortium, Boston, MA

Right Whale Consortium (2008) Northeast Atlantic Right Whale Consortium identification database 10/22/2008. New England Aquarium, Boston, MA

Right Whale Consortium (2012) Northeast Atlantic Right Whale Consortium 2012 annual report card. Report to the Northeast Atlantic Right Whale Consortium November 2012. North Atlantic Right Whale Consortium, Boston, MA

Rosenbaum HC, Brownell RL, Brown MW, Schaeff C and others (2000) World-wide genetic differentiation of Eubalaena: questioning the number of right whale species. Mol Ecol 9:1793-1802

> Saher DJ, Schmiegelow FKA (2005) Movement pathways and habitat selection by woodland caribou during spring migration. Rangifer 25:143-154

Sameoto DD, Herman AW (1990) Life-cycle and distribution of Calanus finmarchicus in deep basins on the Nova Scotia Shelf and seasonal changes in Calanus spp. Mar Ecol Prog Ser 66:225-237

Schick RS, Halpin PN, Read AJ, Slay CK and others (2009) Striking the right balance in right whale conservation. Can J Fish Aquat Sci 66:1399-1403

Stone GS, Kraus SD, Prescott JH, Hazard KW (1988) Significant aggregations of the endangered right whale, Eubalaena glacialis, on the continental shelf of Nova Scotia. Can Field Nat 102:471-474

Turchin P (1998) Quantitative analysis of movement: meas- 
uring and modeling population redistribution in animals and plants. Sinauer Associates, Sunderland, MA

van der Hoop JM, Vanderlaan ASM, Taggart CT (2012) Absolute probability estimates of lethal vessel strikes to North Atlantic right whales in Roseway Basin, Scotian Shelf. Ecol Appl 22:2021-2033

van der Hoop JM, Vanderlaan ASM, Cole TVN, Henry AG and others (2014) Vessel strikes to large whales before and after the 2008 Ship Strike Rule. Conserv Lett, doi: 10.1111/conl.12105

Vanderlaan ASM (2009) Estimating risk to the North Atlantic right whale (Eubalaena glacialis) from ocean-going vessels and fishing gear. PhD thesis, Dalhousie University, Halifax

> Vanderlaan ASM, Taggart CT, Serdynska A, Kenney RD, Brown MW (2008) Reducing the risk of lethal encounters:

Editorial responsibility: Ana Cañadas, Madrid, Spain vessels and right whales in the Bay of Fundy and on the Scotian Shelf. Endang Species Res 4:283-297

- Vanderlaan ASM, Corbett JJ, Green SL, Callahan JA and others (2009) Probability and mitigation of vessel encounters with North Atlantic right whales. Endang Species Res 6: 273-285

> Vanderlaan ASM, Smedbol RK, Taggart CT (2011) Fishinggear threat to right whales (Eubalaena glacialis) in Canadian waters and the risk of lethal entanglement. Can J Fish Aquat Sci 68:2174-2193

Whitehead H (2009) SOCPROG programs: analysing animal social structures. Behav Ecol Sociobiol 63:765-778

Winn H, Price C, Sorensen P (1986) The distributional biology of the right whale (Eubalaena glacialis) in the western Northeast Atlantic. Rep Int Whaling Comm Spec Issue 10:129-138

Submitted: April 8, 2014; Accepted: September 30, 2014 Proofs received from author(s): February 16, 2015 